\title{
PENGEMBANGAN TES DIAGNOSTIK TWO TIER MENGGUNAKAN APLIKASI GOOGLE FORM PADA MATERI TEKANAN DI SMP
}

\author{
Agus Setyawati Putri, Haratua Tiur Maria Silitonga, Hamdani \\ Program Studi Pendidikan Fisika FKIP Untan Pontianak \\ Email: putri.agussetyawati@gmail.com
}

\begin{abstract}
This study aims to develop a two-tier diagnostic test using the google form application on pressure materials in junior high schools. Research on the development of a two-tier diagnostic test using the google form application on this pressure material uses research and development $(R \& D)$ methods. This research was carried out in two stages of trial, namely product trials which were carried out at SMP Negeri 1 Sungai Raya and trial usage at SMP Negeri 1 and 9 Sungai Raya. The instrument used is a two-tier diagnostic test which is distributed using the google form application. This study presents 21 items on the diagnostic test divided into two categories moderate and easy. There are 11 questions while the easy questions have 10 questions. The content validity level of this study was 0.74 . Then the reliability shows 0.804 in product trials and 0.711 in usage trials. With a readability level of 4.42, it is categorized as usable in junior high school. Based on the results of panel validation regarding the use of google forms with the Aiken 1 index and some student response data, the google form application is in the high category (77.33\%). So that the google form application can be used for diagnostic test questions.
\end{abstract}

\section{Keywords: Development, Diagnostic Test, Google Form, Identification, Pressure,} Two Tier

\section{PENDAHULUAN}

Fisika merupakan mata pelajaran yang menuntut peserta didik berpikir secara ilmiah dalam mengungkap fenomena alam. Fisika memiliki karakteristik sebagai ilmu pengetahuan yang paling mendasar yang berisi fakta, konsep dan prinsip. Karena itu pentingnya pelajaran fisika bagi peserta didik.

Pemahaman konsep fisika yang dimiliki peserta didik tidak semuanya sesuai dengan konsep para ilmuwan. Dalam keadaan ini pesrta didik disebut miskonsepsi. Miskonsepsi masih menjadi salah satu masalah dalam pembelajaran fisika di sekolah. Banyak penelitian telah dilakukan dalam bidang pendidikan dengan hasil yang menunjukkan bahwa peserta didik memiliki miskonsepsi dan miskonsepsi tersebut mempengaruhi peserta didik dalam belajar dan memahami pelajaran.
Penafsiran konsep yang dimiliki peserta didik tidak semuanya sesuai dengan konsep para ilmuwan. Dalam keadaan ini pesrta didik disebut miskonsepsi. Miskonsepsi tersebut mempengaruhi peserta didik dalam belajar dan memahami pelajaran. Secara umum miskonsepsi dapat ditimbulkan akibat dari peserta didik, pendidik yang mengajar, konteks pembelajaran, cara mengajar dan buku teks. Dalam penelitian ini akan dikembangkan alat yang hanya untuk menggali miskonsepsi pada peserta didik. Adapun pemicu miskonsepsi yang berawal dari peserta didik diantaranya yaitu prakonsepsi peserta didik sebelum memperoleh pelajaran, lingkungan masyarakat dimana peserta didik tinggal, teman, pengalaman hidup terlebih pengalaman menangkap pengertian dan juga minat peserta didik (Suparno, 2013). 
Menurut penelitian yang dilakukan oleh Wulandari (2009) di SMP Negeri 9 Pontianak, persentase miskonsepsi yang ditemui pada peserta didik sebanyak 40 orang adalah $25,64 \%$ tentang pengertian tekanan, 34,62\% pada bejana berhubungan yang menganggap bahwa luas bejana berhubungan berpengaruh terhadap tinggi zat cair,30,77\% pada prinsip Pascal yang menganggap bahwa gaya tekanan yang diberikan bebanding lurus dengan luas penampang dan $56,41 \%$ pada hukum Archimedes.

Untuk menemukan miskonsepsi peserta didik, terdapat berbagai macam teknik yang digunakan. Satu diantara teknik tersebut adalah dengan pemberian tes, jenis tes yang umum digunakan dilembaga pendidikan untuk mendeteksi kesulitan belajar peserta didik adalah tes diagnostik.

Menurut Kamus Besar Bahasa Indonesia, "Tes diagnostik adalah tes untuk mengetahui kelemahan khusus yang dimiliki oleh peserta didik yang tidak berhasil, juga untuk mengetahui kesulitan (kelemahan) dan kekuatan peserta didik dalam suatu mata pelajaran". Sedangkan menurut Sion dan Jingan (2008: 4) menyatakan bahwa tes diagnostok sebagai tes yang memberikan kepada guru informasi tentang kemampuan awal dan miskonsepsi peserta didik sebelum memulai aktivitas belajar. Sehingga dapat dikatakan bahwa tes diagnostik merupakan tes yang memberikan informasi kepada guru mengenai kelemahan peserta didik dalam mata pelajaran sehingga guru bisa memberi penanganan yang tepat.

Menurut Sutrisno (dalam Mahmuda, 2011), tes diagnostik yang baik harus memenuhi enam karakteristik berikut, yaitu: (1) tingkat validasi tinggi, (2) tingkat reliabilitas tinggi, (3) tingkat kesukaran soal yang rendah, (4) item tes dikembangkan bersumber pada konsepsi awal peserta didik, (5) dirancang khusus untuk mendeteksi kesalahan yang umum dialami peserta didik, dan (6) menggunakan bahasa sederhana dan jelas yang dinyatakan dengan tingkat keterbacaan $\leq 6$. Selain itu, tes diagnostik juga harus memenuhi persyaratan tes yang baik.
Pada penelitian ini, tes diangnostik yang dikembangkan adalah tes diagnostik two-tier. Karena tes diagnostik two-tier merupakan alat diagnostik yang efektif. Selain itu tes diagnostik two-tier dapat menurunkan tingkat kesalahan, yaitu kemungkinan peserta didik menebak jawaban (Tuysuz, 2009).

Hal ini diperkuat dari hasil penelitian sebelumnya. Penelitian Ramise (2016) mengungkapkan bahwa hasil two-tier test yang diberikan kepada 31 peserta didik SMP Negeri 20 Pontianak terindefikasi peserta didik mengalami miskonsepsi pada semua indikator materi tekanan dengan besar persentasenya $26,34 \%$. Tes diagnostik twotier atau tes pilihan ganda dua tingkat adalah sebuah tes untuk mendiagnosa miskonsepsi berupa soal pilihan ganda dengan dua tingkat pilihan jawaban. Untuk tingkat pertama berisikan pertanyaan mengenai konsep yang diujikan sedangkan tingkat kedua berisikan alasan untuk setiap jawaban pada pertanyaan di tingkat pertama sebagai bentuk tes diagnosa (Tuysuz, 2009).

Akan tetapi, dalam kondisi saat ini, dimana pandemi virus corona atau Covid-19 akan sulit untuk melakukan penelitian langsung di sekolah. Karena untuk mencegah penyebarannya virus tersebut, pemerintah menyarankan lembaga pendidikan untuk melakukan pembelajaran via online. Sehingga untuk melakukan tes diagnosa peneliti melakukan tes dengan menggunakan google form yang akan disebarkan ke peserta didik.

Google form yaitu aplikasi dari website google yang bermanfaat untuk memberikan peserta didik atau orang lain kuis atau mengumpulkan informasi yang mudah dengan cara yang efisien (Aria, 2016). Google form dapat digunakan dengan mudah dan hasil dari tes dapat langsung dianalisis.

Berdasarkan permasalahan tersebut perlu diketahui kualitas butir tes diagnostik dengan cara mengidentifikasi tes diagnostik two-tier menggunakan aplikasi google form pada materi tekanan yang dirancang sesuai dengan karakteristik tes diagnostik. 


\section{METODE PENELITIAN}

Bentuk penelitian adalah penelitian dan pengembangan (R\&D) untuk mengembangkan diagnostik two-tier test dengan menggunakan aplikasi google form pada materi tekanan di SMP. Penelitian pengembangan ini adalah pembuatan tes diagnostik two-tier test dengan alasan tertutup menggunakan aplikasi google form dengan pelaksanaan penelitian metode $R \& D$ mengikut pada prosedur yang dikembangkan oleh Sugiyono. Populasi penelitian ini adalah peserta didik Sekolah Menengah Pertama Sungai Raya Kabupaten Kubu Raya. Sedangkan Sampel dari penelitian ini adalah peserta didik kelas VIII SMP, yaitu SMP Negeri 1 Sungai Raya dan SMP Negeri 9 Sungai Raya. Prosedur penelitian ini terdiri dari sembilan tahap, yaitu:

\section{Potensi dan Masalah}

Pada penelitian ini pengumpulan informasi potensi dan masalah yaitu dari skripsi dan jurnal yang berkaitan dengan tes diagnostik dan miskonsepsi materi tekanan yang akan dikaji.

\section{Pengumpulan Data}

Dalam penelitian ini rancangan dalam menetukan bentuk penelitian, yaitu berupa tes diagnostik two tiesr test menggunakan aplikasi google form dan materi yang akan dikembangkan adalah materi tekanan zat padat, tekanan zat cair dan hukum archimedes.

\section{Desain Produk}

Ada 4 langkah untuk mendesain produk, yaitu:

a. Menentukan tujuan tes

Tujuan pengembangan instrumen tes diagnostik ini adalah untuk mengetahui miskonsepsi yang dialami peserta didik pada materi tekanan.

b. Menyusun kisi-kisi tes Kisi-kisi tes sesuai dengan tes yang dibuat dengan spesifikasi seperti pada tabel 1 .

Tabel 1. Kisi-kisi tes diagnostik

\begin{tabular}{llll}
\hline No & Miskonsepsi & Indikator Soal & $\begin{array}{l}\text { Nomor } \\
\text { Soal }\end{array}$ \\
\hline 1 & $\begin{array}{l}\text { Semakin besar permukaan bidang } \\
\text { sentuh benda maka tekanan yang } \\
\text { diberikan juga semakin besar }\end{array}$ & $\begin{array}{l}\text { Mengidentifikasi tekanan pada } \\
\text { benda yang berbeda luas } \\
\text { penampangnya }\end{array}$ & 1,2 dan 3 \\
\hline 2 & $\begin{array}{l}\text { Tekanan hidrostatis berbanding } \\
\text { terbalik dengan kedalaman }\end{array}$ & $\begin{array}{l}\text { Mengidentifikasi hubungan } \\
\text { kedalaman dengan besar tekanan }\end{array}$ & 4,5 dan 6 \\
\hline & $\begin{array}{l}\text { Bentuk dan luas penampang } \\
\text { mempengaruhi tekanan hidrostatis } \\
\text { suatu fluida di kedalaman yang } \\
\text { sama }\end{array}$ & $\begin{array}{l}\text { Mengidentifikasi hubungan luas } \\
\text { permukaan dengan besar tekanan }\end{array}$ & 7,8 dan 9 \\
\hline 4 & $\begin{array}{l}\text { Tekanan hidrostatis tidak } \\
\text { dipengaruhi oleh massa jenis zat } \\
\text { cair }\end{array}$ & $\begin{array}{l}\text { Mengidentifikasi hubungan massa } \\
\text { jenis dengan besar tekanan }\end{array}$ & 10,11 dan \\
\hline 5 & $\begin{array}{l}\text { Massa benda mempengaruhi posisi } \\
\text { benda tersebut ketika didalam air }\end{array}$ & $\begin{array}{l}\text { Menentukan posisi benda dengan } \\
\text { massa yang berbeda ketika berada } \\
\text { di dalam air }\end{array}$ & $\begin{array}{l}13,14 \text { dan } \\
15\end{array}$ \\
\hline
\end{tabular}


Benda yang berat akan tenggelam

7 dan benda yang ringan akan terapung
Menganalisis pengaruh massa jenis benda dan massa jenis zat cair
19,20 dan

21 c. Menentukan bentuk tes

Bentuk tes yang akan dikembangkan dalam penelitian ini adalah tes diagnostik two tier dengan tiga pilihan jawaban.

d. Menulis soal tes

Penulisan soal tes dilakukan dengan menjabarkan indikator menjadi pertanyaan yang sesuai dengan bentuk tes yaitu two tier test.

\section{Validasi desain}

Instrumen akan divalidasi secara isi oleh ahli materi dan validasi panel.

\section{Revisi desain}

Hasil validasi dari para validator akan dihitung menggunakan formula Aiken.

6. Menguuji coba produk

Setelah soal direvisi, maka dapat diuji cobakan pada kelompok terbatas. Uji coba produk dengan skala terbatas dilaksanakan di SMP Negeri 1 Sungai Raya.

\section{Revisi produk}

Merevisi produk dengan menjadikan alasan peserta didik pada uji coba produk dengan skala yang kecil untuk menjadi pilihan alasan pada uji coba pemakaian dengan skala yang lebih besar.

\section{Uji coba pemakaian}

Tahapan ini, peneliti kembali melakukan uji coba produk yang telah direvisi dengan sasaran yang lebih luas yaitu SMP Negeri 1 Sungai Raya, dan SMP Negeri 9 Sungai Raya.

9. Revisi berdasarkan dari menguji coba pemakaian

Tahapan ini, merupakan tahapan terakhir dalam penelitian ini. Hasil dari menguji coba pemakaian direvisi kembali dengan menganalisis hasil tes.

Hasil tes akan dianalisis sesuai kriteria tes seperti berikut:

a. Validitas

Validitas tes merupakan kelayakan dari soal tes untuk digunakan. Kelayak butir soal dinyatakan dengan valid atau tidak. Hasil validitas tes diagnostik two tier dapat dilihat tabel 2.

Tabel 2. Validitas

\begin{tabular}{cccccc}
\hline $\begin{array}{c}\text { No. } \\
\text { Soal }\end{array}$ & Validitas & Keterangan & $\begin{array}{c}\text { No. } \\
\text { Soal }\end{array}$ & $\begin{array}{c}\text { Validitas } \\
\text { Butir }\end{array}$ & keterangan \\
\hline $\mathbf{1}$ & 0,73 & Valid & 12 & 0,74 & Valid \\
\hline $\mathbf{2}$ & 0,73 & Valid & 13 & 0,74 & Valid \\
\hline $\mathbf{3}$ & 0,73 & Valid & 14 & 0,74 & Valid \\
\hline $\mathbf{4}$ & 0,73 & Valid & 15 & 0,75 & Valid \\
\hline
\end{tabular}




\begin{tabular}{cccccc}
\hline $\mathbf{5}$ & 0,73 & Valid & 16 & 0,74 & Valid \\
\hline $\mathbf{6}$ & 0,73 & Valid & 17 & 0,75 & Valid \\
\hline $\mathbf{7}$ & 0,73 & Valid & 18 & 0,75 & Valid \\
\hline $\mathbf{8}$ & 0,73 & Valid & 19 & 0,74 & Valid \\
\hline $\mathbf{9}$ & 0,73 & Valid & 20 & 0,75 & Valid \\
\hline $\mathbf{1 0}$ & 0,74 & Valid & 21 & 0,75 & Valid \\
\hline $\mathbf{1 1}$ & 0,73 & Valid & - & - & - \\
\hline
\end{tabular}

b. Reliabilitas

Data yang dihasilkan dianalisis menggunakan program SPSS yang digunakan untuk menganalisis nilai reliabilitas keseluruhan butir soal dengan Cronbach's Alpha sebagai indeks reliabilitasnya.

c. Tingkat kesukaran

Tingkat kesukaran butir tes diartikan menjadi proporsi peserta didik menjawab butir itu dengan benar.

d. Tingkat keterbacaan

Tingkat keterbacaan dinyatakan dalam readability index yang mencakup variabel panjang kalimat(sentencelength) dan panjang kata (word length).

Soal dianalisis berdasarkan kualitas tes dan karakteristik tes diagnostik. Setelah dianalisis, ditentukan soal-soal yang layak untuk digunakan dan tidak layak digunakan. Selanjutnya soal-soal yang memenuhi kriteria tersebut kemudian dirancang hingga menjadi seperangkat instrument tes diagnostik.

\section{HASIL PENELITIAN DAN PEMBAHASAN \\ Hasil}

Penelitian ini dilakukan dua tahap, yaitu uji coba produk dan uji coba pemakaian. Uji coba produk dilakukan pada SMP Negeri 1 Sungai Raya. Pada uji coba produk, soal tes diagnostik two tier menggunakan alasan terbuka. Setelah itu, soal direvisi pada bagian alasan dari soal tes diagnostik two tier. Alasan dari peserta didik pada pengisian soal diuji coba produk dijadikan pilihan alasan untuk diuji cobakan pada uji coba pemakaian. Uji coba pemakaian dilakukan pada dua sekolah, yaitu SMP Negeri 1 Sungai Raya dan SMP Negeri 9 Sungai Raya.

Tes diagnostik yang baik memiliki validitas tinggi, reliabilitas tinggi, tingkat kesukaran rendah, soal mudah dipahami, dirancang untuk menggali kesalahan umum peserta didik, dan soal dikembangkan berdasarkan konsepsi awal peserta didik. Berdasarkan karakteristik tes diagnostik, soal yang memenuhi karakteristik tersebut dapat dilihat pada tabel 3 .

Tabel 3. Kelayakan Soal Tes Diagnostik

\begin{tabular}{|c|c|c|c|c|c|c|c|}
\hline \multirow{2}{*}{$\begin{array}{l}\text { No. } \\
\text { Soal }\end{array}$} & \multicolumn{6}{|c|}{ Karakteristik Tes Diagnostik } & \multirow{2}{*}{ Keterangan } \\
\hline & 1 & 2 & 3 & 4 & 5 & 6 & \\
\hline 1 & $\sqrt{ }$ & $\sqrt{ }$ & $\sqrt{ }$ & $\sqrt{ }$ & $\sqrt{ }$ & $\sqrt{ }$ & Dipakai \\
\hline 2 & $\sqrt{ }$ & $\sqrt{ }$ & $\sqrt{ }$ & $\sqrt{ }$ & $\sqrt{ }$ & $\sqrt{ }$ & Dipakai \\
\hline 3 & $\sqrt{ }$ & $\sqrt{ }$ & $\sqrt{ }$ & $\sqrt{ }$ & $\sqrt{ }$ & $\sqrt{ }$ & Dipakai \\
\hline 4 & $\sqrt{ }$ & $\sqrt{ }$ & $\sqrt{ }$ & $\sqrt{ }$ & $\sqrt{ }$ & $\sqrt{ }$ & Dipakai \\
\hline 5 & $\sqrt{ }$ & $\sqrt{ }$ & $\sqrt{ }$ & $\sqrt{ }$ & $\sqrt{ }$ & $\sqrt{ }$ & Dipakai \\
\hline
\end{tabular}




\begin{tabular}{|c|c|c|c|c|c|c|c|}
\hline \multirow{2}{*}{$\begin{array}{l}\text { No. } \\
\text { Soal }\end{array}$} & \multicolumn{6}{|c|}{ Karakteristik Tes Diagnostik } & \multirow{2}{*}{ Keterangan } \\
\hline & 1 & 2 & 3 & 4 & 5 & 6 & \\
\hline 6 & $\sqrt{ }$ & $\sqrt{ }$ & $\sqrt{ }$ & $\sqrt{ }$ & $\sqrt{ }$ & $\sqrt{ }$ & Dipakai \\
\hline 7 & $\sqrt{ }$ & $\sqrt{ }$ & $\sqrt{ }$ & $\sqrt{ }$ & $\sqrt{ }$ & $\sqrt{ }$ & Dipakai \\
\hline 8 & $\sqrt{ }$ & $\sqrt{ }$ & $\sqrt{ }$ & $\sqrt{ }$ & $\sqrt{ }$ & $\sqrt{ }$ & Dipakai \\
\hline 9 & $\sqrt{ }$ & $\sqrt{ }$ & $\sqrt{ }$ & $\sqrt{ }$ & $\sqrt{ }$ & $\sqrt{ }$ & Dipakai \\
\hline 10 & $\sqrt{ }$ & $\sqrt{ }$ & $\sqrt{ }$ & $\sqrt{ }$ & $\sqrt{ }$ & $\sqrt{ }$ & Dipakai \\
\hline 11 & $\sqrt{ }$ & $\sqrt{ }$ & $\sqrt{ }$ & $\sqrt{ }$ & $\sqrt{ }$ & $\sqrt{ }$ & Dipakai \\
\hline 12 & $\sqrt{ }$ & $\sqrt{ }$ & $\sqrt{ }$ & $\sqrt{ }$ & $\sqrt{ }$ & $\sqrt{ }$ & Dipakai \\
\hline 13 & $\sqrt{ }$ & $\sqrt{ }$ & $\sqrt{ }$ & $\sqrt{ }$ & $\sqrt{ }$ & $\sqrt{ }$ & Dipakai \\
\hline 14 & $\sqrt{ }$ & $\sqrt{ }$ & $\sqrt{ }$ & $\sqrt{ }$ & $\sqrt{ }$ & $\sqrt{ }$ & Dipakai \\
\hline 15 & $\sqrt{ }$ & $\sqrt{ }$ & $\sqrt{ }$ & $\sqrt{ }$ & $\sqrt{ }$ & $\sqrt{ }$ & Dipakai \\
\hline 16 & $\sqrt{ }$ & $\sqrt{ }$ & $\sqrt{ }$ & $\sqrt{ }$ & $\sqrt{ }$ & $\sqrt{ }$ & Dipakai \\
\hline 17 & $\sqrt{ }$ & $\sqrt{ }$ & $\sqrt{ }$ & $\sqrt{ }$ & $\sqrt{ }$ & $\sqrt{ }$ & Dipakai \\
\hline 18 & $\sqrt{ }$ & $\sqrt{ }$ & $\sqrt{ }$ & $\sqrt{ }$ & $\sqrt{ }$ & $\sqrt{ }$ & Dipakai \\
\hline 19 & $\sqrt{ }$ & $\sqrt{ }$ & $\sqrt{ }$ & $\sqrt{ }$ & $\sqrt{ }$ & $\sqrt{ }$ & Dipakai \\
\hline 20 & $\sqrt{ }$ & $\sqrt{ }$ & $\sqrt{ }$ & $\sqrt{ }$ & $\sqrt{ }$ & $\sqrt{ }$ & Dipakai \\
\hline 21 & $\sqrt{ }$ & $\sqrt{ }$ & $\sqrt{ }$ & $\sqrt{ }$ & $\sqrt{ }$ & $\sqrt{ }$ & Dipakai \\
\hline
\end{tabular}

Keterangan:

$1=$ validitas

$2=$ reliabilitas

3 = tingkat kesukaran soal

4 = tingkat keterbacaan soal

5 = dirancang untuk mendeteksi

kesalahan umum peserta didik

$6=$ item dikembangkan berdasarkan konsepsi awal peserta didik

\section{Pembahasan}

Tes diagnostik adalah tes yang digunakan untuk mengetahui kelemahan peserta didik dalam memahami suatu konsep (Rusilowati, 2015). Sebelum tes disebar menggunakan aplikasi google form dan mengetahui kelemahan peserta didik, tes diagnostik akan diidentifikasi kelayakannya oleh validasi ahli materi dan validasi panel.
Penelitian mengidentifikasi tes diagnostik ini menggunakan langkah-langkah penelitian menurut Sugiyono. Ada 9 langkah yang digunakan dalam penelitian ini yaitu potensi dan masalah, pengumpulan data, desain produk, validasi desain, revisi desain, uji coba produk, revisi produk, uji coba pemakaian, dan revisi berdasarkan uji coba pemakaian sampai dihasilkan tes diagnostik tekanan.

Penelitian ini berbentuk two tier test, yaitu soal terdiri dari dua tingkatan, yaitu tingkat pertama adalah pilihan jawaban dan tingkatan kedua adalah pilihan alasan. Untuk penilaian, peserta didik hanya akan dianggap menjawab benar jika memilih jawaban benar pada tingkatan pertama dan alasan yang benar pada tingkat kedua.

Tes diagnostik yang baik memenuhi 6 karakteristik tes, yaitu (1) tingkat validitas 
tinggi, (2) tingkat reliabilitas tinggi, (3) tingkat kesukaran soal rendah, (4) item dibuat dengan bahasa yang sederhana dan jelas, (5) dirancang untuk mendeteksi kesalahan umum peserta didik, dan (6) dikembangkan berdasarkan konsepsi awal peserta didik.

Validitas dalam penelitian ini menggunakan validitas isi dari ahli materi memperoleh nilai sebesar 0,74 termasuk kedalam kategori tinggi dan validasi panel memperoleh nilai sebesar 1 termasuk kategori sangat tinggi.

Reliabilitas soal dianalisis menggunakan SPSS. Pada uji coba produk reliabilitas soal sebesar 0,804 dan termasuk kategori sangat tinggi. Pada uji coba pemakaian reliabilitas soal sebesar 0,711 dan termasuk kategori tinggi. Perbedaan reliabilitas yang dihasilkan pada uji coba produk dan uji coba pemakaian tidak terlalu besar, sehingga soal dianggap reliabel untuk mengungkap miskonsepsi peserta didik (Azwar, 2003).

Pada uji coba produk terdapat 8 soal kategori mudah dan 13 soal kategori sedang. Pada uji coba pemakaian, soal yang termasuk kategori mudah sebanyak 10 soal dan termasuk kategori sedang sebanyak 11 soal. Pada uji coba produk soal dalam kategori mudah lebih sedikit, ini dikarenakan ada peserta didik yang tidak memberikan alasan dari jawaban yang dipilih.

Soal tes diagnostik yang baik diberikan pada tingkat SMP memiliki tingkat keterbacaan di bawah 6 . Tes diagnostik memiliki rata-rata tingkat keterbacaan sebesar 4,42. Dengan demikian tes dapat dipahami oleh peserta didik.

Soal tes diagnostik dibuat untuk mendeteksi kesalahan umum peserta didik. Kesalahan umum peserta didik didapat dari hasil kajian literatur tentang miskonsepsi peserta didik pada materi tekanan. Sehingga diperoleh 7 miskonsepsi yang kemudian dikembangkan menjadi soal tes diagnostik. Berdasarkan hasil validasi yang dilakukan oleh tiga orang validator, pada kriteria soal sesuai dengan miskonsepsi memiliki rata-rata sebesar 0,74. Hasil dari validator menunjukkan bahwa soal yang dikembangkan telah sesuai dengan miskonsepsi.
Soal tes diagnostik dikembangkan berdasarkan Soal

Tes diagnostik dikembangkan berdasarkan konsepsi awal peserta didik. kensepsi awal peserta didik didapat dari hasil uji coba produk. Terdapat 8 miskonsepsi peserta didik yang didapat dari uji coba produk.

Identifikasi tes diagnostik ini juga menggunakan aplikasi google form sebagai media validasi panel dan media tes bagi peserta didik. Penggunaan aplikasi google form ini karena ditinjau dari kondisi saat ini dimana pandemi virus corona atau Covid-19 sehingga akan sulit untuk melakukan penelitian langsung ke sekolah.

Google form sendiri adalah alat yang berguna untuk membantu anda merencanakan acara, mengirim survei, memberikan peserta didik atau orang lain kuis, atau mengumpulkan informasi yang mudah dengan cara yang efisien (Aria, 2016). Form juga dapat dihubungkan ke spreadsheet. Jika spreadsheet terkait dengan bentuk, tanggapan otomatis akan dikirimkan ke spreadsheet. Sehingga pada saat validasi panel dan peserta didik memberi respon maka data akan langsung dapat dianalisi.

\section{SIMPULAN DAN SARAN Simpulan}

Secara umum hasil penelitian dapat diasumsikan bahwa tes diagnostik two-tier yang dikembangkan pada penelitian ini telah memenuhi kualitas dan karakteristik tes diagnostik yang baik dan layak digunakan untuk menggali miskonsepsi peserta didik pada materi tekanan di SMP.

\section{Saran}

Soal yang dikembangkan dapat digunakan untuk menjelaskan miskonsepsi yang dialami peserta didik pada materi tekanan zat serta dapat digunakan pada media google form. Namun, berdasarkan keterbatasan penelitian yang telah dilakukan, maka saran dari peneliti perlu ditinjau kembali 
pemilihan sekolah yang tepat untuk penggunaan media tes berbasis online.

\section{DAFTAR RUJUKAN}

Aria (2016). Mengenal Google Form untuk Kebutuhan Survey Anda. (online) (https://idcloudhost.com/mengenalgoogle-form-untuk-kebutuhan-surveyanda/, diakses, 2 April 2020).

Mahmuda, D. (2011). Secondary Analysis Tentang Tes Diagnostik Skripsiskripsi Mahasiswa Pendidikan Fisika FKIP Untan Tahun 2007-2009 Pada
Materi Mekanika. Pontianak: FKIP Untan (Skripsi).

Ramise, M. (2016). Remediasi Miskonsepsi Siswa Materi Tekanan Menggunakan Strategi Quantum Teaching di SMP Negeri 20 Pontianak. Pontianak: FKIP Untan (skripsi).

Rusilowati, A. (2017). Pengembangan Instrumen Penilaian. Semarang: University Press.

Sugiyono, (2014). Metode Penelitian Manajemen. Bandung: Alfabeta. 